\title{
The Impact of Corporate Governance Practices on Corporate Financial Performance in Ethiopia
}

\author{
Biruk Ayalew Wondem ${ }^{1 *}$, Gurdip Singh Batra ${ }^{2}$ \\ ${ }^{1}$ Department of Accounting and Finance, Debre Markos University, Debre Markos, Ethiopia; ${ }^{2}$ Faculty of Business Studies, Punjabi \\ University, Patiala, India
}

\begin{abstract}
This research was carried out to examine the impact of corporate governance practices on share companies' financial performance by using panel regression approach. Data sources from 24 share companies for five years. The findings of robust FGLS estimation of panel regression using ROA and ROE as measures of financial performance revealed board of directors' gender diversity (BDGD sig. at 5\%) and size of share companies (SIZE sig. at 1\%) have a positive association with return on assets and board of directors meeting attendance rate (BDMAR) in person has a positive association but not significant. The board of directors' size (BS sig. at 5\%), board of directors meeting frequency (BMF sig. at 5\%) and board of directors' leadership practice (BDLPR sig. at 1\%) have a negative impact on return on assets. The paper also empirical findings ROE has a significant and positive association with board meeting frequency $(p<0.05)$; board of directors' gender diversity $(p<0.05)$ and size of share company $(p<0.01)$. And board of directors meeting attendance rate in person has a significant and negative relationship with $\mathrm{ROE}(p<0.01)$. However, no significant but negative association was found between ROE with board size and board of directors' leadership practice. State ownership has also a positive association with ROA as well as ROE. The model is good fit with R-square value of 84 and $93 \%$ for model one (ROA) and two (ROE) respectively. The study concluded that corporate governance practices of Ethiopian share companies are not going on the way what it should be in line with the changing landscape of corporate business environment for the reason that boards of directors elected and working in companies lack true independence and the required skills and knowledge. Awareness gap as to corporate governance; mal-governance practice in recruitment and selection, lack of up to date regulatory framework; absence of specific policy framework, national principles and codes results unstructured governance practices to be practiced. All these cause the problem of ethics, disclosure and transparency, corruption, nepotism, tribalism etc. and this research can be extended further by incorporating variables that can show the external corporate governance practices and other sectors.
\end{abstract}

Keywords: Corporate governance mechanisms; Corporate performance; Panel regression; Share companies; Ethiopia

\section{INTRODUCTION}

Good corporate governance practice is a gauge how companies are directed and controlled become a key topic and received wide attention both in practice [1-3] and in academic research [4-6]. International financial scandals at WorldCom, Enron, and other companies highlighted the importance of good corporate governance practices and the oversight of a corporation's managements and ethics of board of directors in the company's governance are major concerns [7]. The research gap is in case of underdeveloped countries dearth of research. CG practices of Ethiopian share companies are not going on the way what it should be however a changing landscape of corporate business environment in the country where the activities of corporate business operations today are like those developed nations but not in governance practice. Furthermore, the issue of corporate governance practices on firm financial performance has been exhaustively studied for decades' especially in developed countries and yet ambiguity and incongruence continue to prevail [8]. Consequently, the study crafted to examine the impacts of corporate governance practices on share companies' financial performance in Ethiopian where companies operating their business in the absence of organized stock market, up to date regulatory framework and corporate governance systems that can induce good corporate governance and performance. The study also intends to contribute to the corporate governance literature in under developed countries context where

${ }^{*}$ Correspondence to: Biruk Ayalew Wondem, Department of Accounting and Finance, Debre Markos University, Debre Markos, Ethiopia, Tel: +00251911739234; E-mail: birukayalew1983@gmail.com

Received: February 27, 2019; Accepted: March 15, 2019; Published: March 21, 2019

Citation: Wondem BA, Batra GS (2019) The Impact of Corporate Governance Practices on Corporate Financial Performance in Ethiopia. Int J Account Res 7:196. doi: 10.35248/2472-114X.19.7.196

Copyright: @ 2019 Batool A, et al. This is an open-access article distributed under the terms of the Creative Commons Attribution License, which permits unrestricted use, distribution, and reproduction in any medium, provided the original author and source are credited. 
the dearth of literature and professionals actually sited seriously.

\section{EMPIRICAL STUDIES AND HYPOTHESIS OF THE STUDY}

\subsection{Board size}

In Ethiopia, the corporate governance directive for financial institutions issued by NBE in 2015; specify the size of the board to be at least nine in insurance and banking sector and seven in microfinance sector. However, the board of directors as the most important control mechanisms in a company's internal governance structure [9] as to their size there are two schools of thoughts. One state smaller board size often is more cohesive and work more effectively than larger boards [10]. Studies supporting this school of thought [11-18] depicted there is significant negative correlation between board size and corporate performance measures. The second school of thought argues large board size improves company performance decision making precision is reduced if the number of directors is too small because there may not be adequate discussion of issues involved. Studies empirically find board size have positive significant influence on company performance [19-25]. Still inconclusive result is reflected. In this research the ability of board of directors to control and promote value-creating activities is more likely to increase with the increase of directors on the board with more directors, the collective experience and expertise of the board will increase, and therefore, the financial performance of companies would be higher [26]. Therefore, the study hypothesized that: the board of directors' size is positively related with share companies' financial performance.

\section{Board meeting frequency}

According to Ethiopian National Bank draft corporate governance directive 2014 and (directives No. SBB/62/2015), financial institutions are encouraged to have regular board meetings at least once in a month; board meetings and attendance of the meetings are considered to be important channels through which directors obtain firm specific information and able to fulfil their monitoring role. Board meeting frequency, measured by the number of meetings the board holds on average each year, is an indicator of board involvement and diligence in strategic decision-making as cited by Li [27].

Board meetings are significantly and positively associated with company performance Adawi and Rwegasira [28] and Satirenjit, et al. [25] specifically test the effects of board meeting on firm accounting performance they concluded that board diligence in terms of board meetings is found to have an adverse effect on firm performance. However contradictory findings Malik and Nehra [29] stated the more frequent the meetings, closer the supervision and control over managers, the more relevant would be the advisory role. The bulk of board's work is carried out in meetings and board meetings can therefore be used to measure the contribution by board members to ensure their full commitment and engagement in overseeing the running of the company business and monitoring management it is hypothesized that: There is a positive relationship between board meeting frequency and Share Company's financial performance.

\section{Board of directors leadership practice}

Best practice boards have the capacity to make objective and unbiased economic decisions. Objective and unbiased judgment is also necessary to protect the company and its shareholders from the possible negative effects of conflicts of interest. The way boards typically achieve these goals is by having independent board members (IFC, 2012). Fama and Jensen [9] described the role of the board of directors as an integral internal corporate governance mechanism in mitigating agency problem. The board reduces the agency conflict by separating the management and control aspects of the decision-making process. The renowned agency theory and Corporate Governance (CG) codes around the world advocate independence of corporate boards [30]. Therefore, in this research since there is no the practice of outside directors in the governance practice in Ethiopian context the board of directors' leadership practice is measured by using dummy variable of duality as a proxy variable i.e. whether the chief executive officer is distinct from the chairman of the board to ensure the boards independence due to the fact that CEO duality is an obstacle for the independence of the board of directors [31]. Fama and Jensen [9] claims that CEOs who also hold the board chair position exert undue board influence, compromising the strength of board's governance furthermore Finkelstein and D'Aveni [32] noted that according to agency theory joint structure promotes $\mathrm{CEO}$ entrenchment by reducing board monitoring effectiveness. The Cadbury Report of 1991 supported the two posts should be separated. Hence in this study duality is an indicator of weak governance practice which causes weak company performance the study hypothesis: There is a negative relationship between board of directors' leadership practice and Share Company's financial performance.

\section{Board room gender diversity}

The other most common features of board of directors that receives progressively attentions in the corporate governance literature and regulatory discussions now a day is board room diversity increasingly considered as a significant mechanism of good corporate governance. Thus, the question arises whether a heterogeneously or rather a homogenously composed board contributes to the efficiency of a company's management and monitoring. Management board diversity is characterized by attributes like gender, age, nationality and functionality [33]. The issue of women on board is gaining attention globally and gender composition of the board of directors is one current governance issue facing corporate organization today [34]. The composition of the board fundamentally determines its effectiveness. Effective boards have diversity, different backgrounds, and a multiplicity of skills and opinions. One of the most significant governance issues currently facing the managers, directors, and shareholders of the modern corporation is the gender, racial, and cultural composition of the board of directors [35]. Gender diversity is of the factors discussed in corporate governance and performance research and empirical findings confirmed that companies with the highest proportion of females in the board room outperform than lowest proportion [36-40]. These studies pointed out woman has a better overview on the complex issues, attending more boards meetings and tend to influence larger public transparency. Catalyst [41] stated that the group of companies with the highest representation of women on their top management teams experienced better financial performance than the group of companies with the lowest representation of women. The study hypothesizes: The greater the share company's proportion of female directors on its board room the better its financial performance. 


\section{Board of directors meeting attendance rate}

An essential way that a board exerts its influence on its company is coming through decisions and plans made in board meetings. The directors of a share company have to attend their board meetings to monitor, stipulate and supervise the company or to make strategic decisions. Failure to regularly attend board meetings can be seen as a director is unwilling or unable to fulfil his or her duties whereas attending board meetings is a signal to accomplish a director's responsibility and should be associated with subsequent higher company performance. Empirical findings indicated the tendency to be absent from board meetings is associated with the high number of board meetings whilst the tendency to attend more board meetings is associated with the increase in age, tenure, and director ownership [42]. Min and Chizema [43] stated regular board meeting attendance is important in improving the effectiveness of a governance system. As per the requirement of licensing and supervision of banking business bank corporate governance directives no. SBB/62/2015 and licensing and supervision of insurance business corporate governance directives no. SIB $/ . . . / 2015$, financial share companies are encouraged to have regular board meetings held at least once in a month for discharging duties and responsibilities and a director shall attend in person at least $75 \%$ of the board meetings within a year. Failure to do so, unless adequately justified and accepted by ordinary general meeting of shareholders, will render automatic cancellation of his/her/its seat on the board. Therefore, the study hypothesis: The higher the proportion of Share Company's board of directors meeting attendance rate in person has a positive correlation with Share Company's financial performance. In addition, in most corporate governance research studies, firm size and leverage were used as control variables and the natural logarithm of total assets were used as a proxy for firm size while the ratio of total noncurrent liabilities divided by total assets were used as a measure of leverage in this study.

\section{Corporate performance measures}

One of the most important functions that corporate governance can play is in ensuring the quality of the financial reporting process. Better corporate governance is supposed to lead to better corporate performance by preventing the confiscation of controlling shareholders and ensuring better decision making. Most previous research considered corporate performance as dependent variable and measured on the basis of accounting measures such as ROA, ROE, NPM, EPS etc., for the short term analysis of operating performance; and market measures such as Tobin's $Q$ and market to book value ratio the most widely used long-term proxy for firm valuation of performance [44-46]. In Ethiopia there is no organized stock market indicating the market information of firms hence the market measuresare not considered as a proxy to measure share companies' long term performance. In this study the accounting measures of profitability measures of short term performance are the appropriate and the most common measures used to gauge financial performance of return on asset (ROA) and return on equity (ROE) used. Return on Assets reflects the ability of company's management to generate profits from the company's assets, although it may be biased due to off-balance-sheet activities $[25,47]$.

ROA $=\frac{\text { Annual Net Income After Tax }}{\text { Total Assets }}$
Return on equity is the other accounting based measures of performance in corporate governance literature and research [25,44-46]. It is the amount of net income returned as a percentage of shareholder's equity. It measures profitability of company by evaluating that how much income a corporation earns with the capital contributed by shareholders. Return on equity is a very important measure because it reflects the productivity of the ownership capital employed and represented in term of percentage. It is calculated as:

$$
\text { ROE }=\frac{\text { Annual Net Income After Tax }}{\text { Shareholders Equity }}
$$

\section{RESEARCH METHODOLOGY}

\section{The linear panel regression model}

The researcher employed an econometric model of linear panel regression model. A panel data analysis allowed in identifying the effects and relationships of various corporate governance practices on corporate performance of different companies. The panel data estimation is often considered to be an efficient analytical method in handling econometric data [48-51]. The basic Pooled linear panel econometric model is specified as follows:

$\mathrm{SHACOPERF}_{\text {it }}=\beta 0+\beta 1 \mathrm{BS}_{\mathrm{it}}+\beta 2 \mathrm{BMF}_{\mathrm{it}}+\beta 3 \mathrm{BDGD}_{\mathrm{it}}+\beta 4 \mathrm{BDMAR}_{\mathrm{it}}+\beta 5$ $\mathrm{BDLPR}_{\mathrm{it}}+\beta 6 \mathrm{SIZE}_{\mathrm{it}}+\mathcal{E}_{\mathrm{it}}$

Where $i=1,2 \ldots n$ is the share company index, $t=1,2 \ldots \mathrm{T}$ is the time index,

SHACOPERF $_{\text {it }}=$ share company i performance at time $t$ as expressed and measured by ROA and ROE,

$\beta_{0}=$ Intercept,

$\mathrm{BS}_{\mathrm{it}}=$ Board size of share company $\mathrm{i}$ at time $\mathrm{t}$,

$\mathrm{BMF}_{\mathrm{it}}=$ Board of directors meeting frequency of share company $\mathrm{i}$ at time $t$ per annual,

$\mathrm{BDMAR}_{\mathrm{it}}=$ Board of directors meeting attendance rate in person of share company $i$ at time $t$,

$\mathrm{BDGD}_{\mathrm{it}}=$ Board of directors' gender diversity of share company $\mathrm{i}$ at time $t$,

$\mathrm{BDLPR}_{\mathrm{it}}=$ Board of directors' leadership practice for share company $\mathrm{i}$ at time $\mathrm{t}$,

$\operatorname{SIZE}_{\mathrm{it}}=$ Size of share company $i$ at time $t$,

$\varepsilon_{i t}=$ The error term for share company $i$ at time $t$.

\section{Panel regression model approaches}

For panel data there three model approaches to be employed the common constant model, fixed effect model and random effect model $[48,49,52,53]$. To determine which approach to employ the Hausman test was carried out in this study.

\section{Data sources}

Secondary data of financial reports obtained from national bank of Ethiopia and the study used panel datasets for the study periods of 2011-2015 of 24 share companies. Data on board of directors' characteristics and governance practices collected directly from each of financial share companies through questionnaire. 


\section{Data analysis}

Based on diagnostics test results the study used fixed effect model and General Least Square (GLS) multivariate regression analysis estimator is employed to analyse or evaluate the influence of each corporate governance practices on share companies' financial performance in Ethiopia and to test the hypothesis developed. It is obvious from classical theory that the GLS estimator is unbiased and (from the Gauss-Markov theorem) it is the best linear unbiased estimator (BLUE) of the parameters. In this study to decide which panel data estimator to use the HETCOEF of each model were taken into account based on the recommendation given by Reed and Ye [54] for large values of groupwise heteroscedasticity (HETCOEF> 1.67), both FGLS (groupwise heteroscedasticity) and FGLS (groupwise heteroscedasticity ${ }^{+}$serial correlation) provides consistent efficiency gains relative to other estimators. In contrast, no one estimator is distinctly preferred when HETCOEF falls below this value. Hence the researcher used the robust weighted least square technique of heteroscedasticity consistent estimation method of FGLS because of the fact that the estimator helps to make efficient estimate on the models used with robust result. Eviews-7 and Eviews-9SV used for analysis.

\section{RESULTS AND DISCUSSION}

\section{Introduction}

Descriptive analysis was performed and then specification testing of the panel model which involved testing for unit root, pool ability and residual based tests (cross-sectional dependence, autocorrelation and heteroscedasticity) carried out before fitting the suggested models.

\section{Descriptive statistics analysis}

The common statistics results for all 24 share companies for the study periods of 2011-2015, are illustrated in the following two tables. The result in Table 1 portrayed the average ROA ratio shows 4.35 , while the standard deviation was found to be 0.99 from the mean value and the minimum and maximum being 2.89 and 6.66, respectively showing less dispersion and the average value of ROE was 29.41 having a minimum value of 10.70 and a maximum value of 49.18. The standard deviation of ROE was 9.31 which show the variation high variation of performance among the share companies with regard to ROE depicted.

The summary statistics for the predictors used reported in Table 2. The average board size of share companies for the study period is

Table 1: The results of descriptive statistics of share companies performance variables. Source: Worked out from secondary data and result from the package.

\begin{tabular}{lcc}
\hline Statistics & ROA & ROE \\
\hline Mean & 4.351083 & 29.41417 \\
\hline Maximum & 6.66 & 49.18 \\
\hline Minimum & 2.89 & 10.7 \\
\hline Std. Dev. & 0.989683 & 9.312376 \\
\hline Skewness & 0.478005 & 0.05865 \\
\hline Kurtosis & 2.239188 & 2.234068 \\
\hline Jarque-Bera & 7.463944 & 3.002056 \\
\hline Probability & 0.023946 & 0.222901 \\
\hline Observations & 120 & 120
\end{tabular}

Table 2: Descriptive statistics of share companies corporate governance practices. Source: Worked out from secondary data and result from the package.

\begin{tabular}{lccccc}
\hline Statistics & BS & BMF & BDGD & BDMAR & SIZE \\
\hline Mean & 9.191667 & 23.14167 & 10.6345 & 82.02783 & 14651.67 \\
\hline Maximum & 12 & 48 & 40 & 95 & 246772.7 \\
\hline Minimum & 6 & 5 & 0 & 70 & 65.36000 \\
\hline Std. Dev. & 1.513501 & 10.44578 & 8.411971 & 6.026206 & 44691.42 \\
\hline Skewness & 0.329601 & 0.48136 & 0.506885 & -0.123507 & 4.128668 \\
\hline Kurtosis & 2.566035 & 2.754376 & 3.244968 & 2.008621 & 19.22881 \\
\hline Jarque-Bera & 3.11436 & 4.935802 & 5.438701 & 5.219244 & 1657.789 \\
\hline Probability & 0.210729 & 0.084763 & 0.065918 & 0.073562 & 0 \\
\hline Observations & 120 & 120 & 120 & 120 & 120
\end{tabular}

nearly with the minimum size of 6 and maximum of 12 members ranged within the requirements of the commercial code under Art.347 (2) stated an incorporated body should have a minimum of 3 and a maximum of 12 board of directors; Even if, banking sector share companies shall have at least nine board of directors as per licensing and supervision of banking business bank corporate governance directives no. sbb/62/2015 complied with the average of the results of the study.

The board's average annual meeting frequency of about 23 was with minimum board meeting frequency of 5 and maximum of 48 board meetings per year. The standard deviation was 10.44 pointed out high dispersion of board meeting frequency among share companies from the average value. The average proportion of female board of directors was $10.63 \%$ having a minimum of zero percent and a maximum of $40 \%$ and the standard deviation of 8.41 indicating high dispersion of in female involvement in the board of directors. Average of the board of directors meeting attendance rate is $82 \%$ having a minimum of $70 \%$ and a maximum of $95 \%$ and the standard deviation of 6.03 implies there is less variation in board of directors' board meeting attendance rate among the share companies under this study. With respect to the average of sample share companies size is Br.14651.67 million having a minimum value of Br.65.36 million and a maximum of 246772.7 million and the standard deviation of share company size among the sample share companies was Br.44691.42 million indicated size of the share companies selected for the study is heterogeneous and highly varied considering the minimum and maximum size and also standard deviation values.

\section{Specification test results}

Unit root test: Unit root test performed to avoid spurious regressions to check the stability of the panel data before the panel estimation assessed. This study employed Levin, Lin and Chu $t^{*}$ (LLC) test for testing. The test employed at level by using individual fixed effects as regressors, and automatic lag difference term and bandwidth choice using the Schwarz criterion for the lag differences and the Newey-West method (NWM) and the Bartlett kernel for the bandwidth. The results in Table 3 indicated the $p$-values are less than $\alpha(0.05)$ for all of the variables so reject $\mathrm{H}_{0}$ the assumption before the estimation of the multi-variate regression model is met i.e., all the variables are stationary at level that shows variables are not stationary over time.

As shown above the result in Table 3, all variables are integrated of order zero. This validates the panel data could be used to perform 
authentic regressions. For a stationary series, 'shocks' to the system will gradually die away. That is, a shock during time $t$ will have a smaller effect in time $t+1$, a smaller effect still in time $t+2$, and so on. So that the use of non-stationary data can lead to spurious regressions because of the persistence of shocks will always be infinite and for a non-stationary series the effect of a shock during time $t$ will not have a smaller effect in time $t+1$, and in time $t+2$, $\mathrm{t}+3$, etc. [49].

Hausman tests: Once Hausman test is carried out and ensured the random effect is not appropriate next which model to select either pooled or fixed effect model were evaluated by using likelihood ratio test of redundant fixed effects tests. To evaluate the pool ability of the samples or to determine whether the fixed effects are necessary or not a redundant fixed effect test were carried out in EViews. There are three different redundant fixed effect tests, each in both $\chi 2$ and F-test versions. The probability value of F-test statistic result $(p>0.0000)$ for both models, indicated the individual effect was significant so that mixed regression could not be used instead the panel model had to be used. In deciding which panel model to use the random effects or the fixed effects model is determined by the Hausman test result. The null hypothesis of the test was that the random effect method is the preferred regression method. Table 4 depicted the fixed effect is the appropriate approach and the study used fixed effect model for further analysis because the p-value for the test is less than $1 \%$, indicating that the random effects model is not appropriate and that the fixed effects specification is to be preferred [49].

Residual tests: After checking that the fixed effects model is the appropriate model for further analysis the presence of nonspherical errors of Cross-Sectional Dependence, Serial Correlation and Heteroscedasticity were checked.

Tests for cross-sectional dependence: Contemporaneous correlation test carried out in this study with the null hypothesis of no crosssection dependence in residuals. The study confirmed the Pesaran

Table 3: The Results of Levin, Lin and Chu t* (LLC) Unit Root Test. Source: Worked out from secondary data and result from the package.

\begin{tabular}{ccc}
\hline Variables & $p$-value & Statistics \\
\hline ROA & 0 & -16.1918 \\
\hline ROE & 0 & -13.549 \\
\hline BS & 0.0154 & -2.16011 \\
\hline BMF & 0 & -6.67196 \\
\hline BDGD & 0 & -9.82665 \\
\hline BDMAR & 0.0024 & -2.81565 \\
\hline SIZE & 0 & -19.1026 \\
\hline
\end{tabular}

Table 4: The results of correlated random effects Hausman Test. Source: Worked out from secondary data and result from the package.

A. Correlated random effects - Hausman Test Model one

Equation: Untitled

Test cross-section random effects

\begin{tabular}{lccc}
\hline Test summary & Chi-Sq. Statistic & Chi-Sq. d.f. & Prob. \\
\hline Cross-section random & 80.847942 & 6 & 0 \\
\hline
\end{tabular}

B. Correlated random effects - Hausman Test Model two

Equation: Untitled

Test cross-section random effects

\begin{tabular}{lccc}
\hline Test summary & Chi-Sq. Statistic & Chi-Sq. d.f. & Prob. \\
\hline Cross-section random & 34.08033 & 6 & 0 \\
\hline
\end{tabular}

CD test indicated an insignificant $p$-value of 0.1660 and 0.2214 respectively for model one and two indicating the absence of cross sectional dependence of the residuals.

Tests for serial correlation: One of the assumptions of the regression model is that the errors are uncorrelated [55]. The best-known test statistic for serial correlation is the statistic proposed by Durbin and Watson and commonly referred to as the DW statistic. The result indicated that there is no autocorrelation. In case of the first and second model the value of DW 1.8 and 2.12 respectively which is approximately 2.0 implies there is no the problem of autocorrelation.

Tests for heteroscedasticity: The assumption where the variances of the error terms of a regression model are assumed to be constant over different sample observations. The heteroscedasticity test was done with help of Breusch-Pagan Lagrange Multiplier test and HETCOEF as a measure of group wise heteroscedasticity. The result indicated in both models that LM-stat $<\chi 2_{6,5 \%}$. The residuals in the regression have the same variance in both models and the null hypothesis should be accepted. Group wise heteroscedasticity coefficient (HETCOEF) as a measure of group wise heteroscedasticity was determined for both models by following Reed and Ye (2011) procedures and recommendation. Subsequently, HETCOEF for model one is 1.694023-1.69 and for model two is $1.45968-1.46$. This implies the degree of group wise heteroscedasticity present in model one which is greater than the value of 1.67 thresh hold but not in model two that shows a value of 1.46 which is less than 1.67 .

\section{RESULTS AND DISCUSSIONS}

Correlation analysis is an acceptable technique for measuring the association between variables Agung [50] stated that most students and less experienced researchers do not pay much attention to, or do not even know that correlation analysis can be used to replace data analysis based on simple linear regression. To identify the relationship among the corporate governance practice variables and share company financial performance Pearson correlation coefficients were used. Table 5, reveals the relationships of the dependent variables with the independent variables. Therefore, ROA has negative significant relationship with board size; positive significant relationship with board of directors meeting attendance rate and size of share company at $p$-value less than $1 \%$ in all cases. But it has negative not significant relationship with board of directors meeting frequency and board of directors' leadership practice and positive but not significant relationship with board of directors' gender diversity. Further, the result pointed out return on equity has a negative significant correlation with board size and board meeting frequency at significant level of $1 \%$, however, no significant correlation with board of directors' gender diversity and size of Share Company but positive relationship; board of directors' meeting attendance rate and board of directors' leadership practice having negative relationship.

\section{Panel regression estimation and hypothesis results and discussion}

FGLS estimation results: The result in Table 6 illustrated board of directors' size (BS, sig.5\%), board of directors meeting frequency (BMF, sig. $5 \%$ ) and board of directors' leadership practice (BDLPR, sig. $1 \%$ ) reflected a negative impact on financial performance ROA. And board of directors' gender diversity (BDGD, sig. 5\%) and 
Table 5: The results of correlation matrix of the variables during 2011-2015. Source: Worked out from secondary data and results from the package.

\begin{tabular}{|c|c|c|c|c|c|c|c|c|}
\hline \multicolumn{9}{|c|}{ Correlation } \\
\hline Prob. & ROA & ROE & BS & BMF & BDGD & BDMAR & BDLPR & SIZE \\
\hline \multirow[t]{2}{*}{ LOGROA } & 1 & & & & & & & \\
\hline & $\ldots$ & & & & & & & \\
\hline \multirow[t]{2}{*}{ ROE } & 0.491652 & 1 & & & & & & \\
\hline & $0.0000^{* * *}$ & $\ldots$ & & & & & & \\
\hline \multirow[t]{2}{*}{ BS } & -0.343023 & -0.508792 & 1 & & & & & \\
\hline & $0.0001^{* * *}$ & $0.0000^{* * *}$ & $m$ & & & & & \\
\hline \multirow[t]{2}{*}{ BMF } & -0.094675 & -0.44552 & 0.393197 & 1 & & & & \\
\hline & 0.3037 & $0.0000^{* * *}$ & $0.0000^{* * *}$ & $\ldots$ & & & & \\
\hline \multirow[t]{2}{*}{ BDGD } & 0.09903 & 0.103735 & 0.21374 & 0.076838 & 1 & & & \\
\hline & 0.2819 & 0.2595 & $0.0191^{* *}$ & 0.4042 & $\ldots$ & & & \\
\hline \multirow[t]{2}{*}{ BDMAR } & 0.304284 & -0.045763 & 0.074316 & 0.156799 & 0.152153 & 1 & & \\
\hline & $0.0007^{* * *}$ & 0.6197 & 0.4198 & $0.0872^{*}$ & $0.0971^{*}$ & $\ldots$ & & \\
\hline \multirow[t]{2}{*}{ BDLPR } & -0.021026 & -0.118359 & 0.102935 & 0.101898 & -0.00739 & 0.119923 & 1 & \\
\hline & 0.8197 & 0.1979 & 0.2632 & 0.2681 & 0.9362 & 0.192 & $m$ & \\
\hline \multirow[t]{2}{*}{ SIZE } & 0.316522 & 0.071578 & 0.330148 & 0.062432 & 0.047585 & -0.088211 & 0.110769 & 1 \\
\hline & $0.0004^{* * *}$ & 0.4372 & $0.0002^{* * *}$ & 0.4981 & 0.6058 & 0.338 & 0.2284 & $\ldots$ \\
\hline
\end{tabular}

***, **, and * indicate the significance level at 1,5 and $10 \%$, respectively.

Table 6: FGLS estimation. Source: Worked out from secondary data and results from the package.

\begin{tabular}{|c|c|c|c|c|c|c|}
\hline \multirow[t]{3}{*}{ Variables } & \multicolumn{6}{|c|}{ FGLS Fixed Effect Results } \\
\hline & \multicolumn{3}{|c|}{ (1) Model One(ROA) } & \multicolumn{3}{|c|}{ (2) Model Two(ROE) } \\
\hline & Coef. & Std. Error & T-Statistic & Coef. & Std. Error & T-Statistic \\
\hline \multirow[t]{2}{*}{ Constant } & -0.072352 & \multirow[t]{2}{*}{0.270292} & \multirow[t]{2}{*}{-0.267682} & 15.99663 & \multirow[t]{2}{*}{3.690578} & \multirow[t]{2}{*}{4.334451} \\
\hline & -0.7896 & & & $(0.0000)^{* * *}$ & & \\
\hline \multirow[t]{2}{*}{ BS } & -0.025599 & \multirow[t]{2}{*}{0.012758} & \multirow[t]{2}{*}{-2.006399} & -0.339972 & \multirow[t]{2}{*}{0.311518} & \multirow[t]{2}{*}{-1.091338} \\
\hline & $(0.0478)^{* *}$ & & & -0.278 & & \\
\hline \multirow[t]{2}{*}{ BMF } & -0.005814 & \multirow[t]{2}{*}{0.002716} & \multirow[t]{2}{*}{-2.140866} & 0.208034 & \multirow[t]{2}{*}{0.092506} & \multirow[t]{2}{*}{2.248873} \\
\hline & $(0.0350)^{* *}$ & & & $(0.0270)^{* *}$ & & \\
\hline \multirow[t]{2}{*}{ BDGD } & 0.005267 & \multirow[t]{2}{*}{0.002386} & \multirow[t]{2}{*}{2.207945} & 0.061219 & \multirow[t]{2}{*}{0.025968} & \multirow[t]{2}{*}{2.357497} \\
\hline & $(0.0298)^{* *}$ & & & $(0.0206)^{* *}$ & & \\
\hline \multirow[t]{2}{*}{ BDMAR } & 0.002232 & \multirow[t]{2}{*}{0.002322} & \multirow[t]{2}{*}{0.961398} & -0.201692 & \multirow[t]{2}{*}{0.025876} & \multirow[t]{2}{*}{-7.794654} \\
\hline & -0.3389 & & & $(0.0000)^{* * *}$ & & \\
\hline \multirow[t]{2}{*}{ BDLPR } & -0.097682 & \multirow[t]{2}{*}{0.034076} & \multirow[t]{2}{*}{-2.866563} & -0.151186 & \multirow[t]{2}{*}{1.458116} & \multirow[t]{2}{*}{-0.103686} \\
\hline & $(0.0052)^{* * *}$ & & & -0.9176 & & \\
\hline SIZE & 0.220039 & 0.03908 & 5.630471 & 3.652794 & 0.332229 & 10.9948 \\
\hline & $(0.0000)^{* * *}$ & & & $(0.0000)^{* * *}$ & & \\
\hline R-Square & & 0.843535 & & & 0.931768 & \\
\hline Adjusted R-Square & & 0.793118 & & & 0.909783 & \\
\hline F- Statistics & & 16.73128 & & & 42.38056 & \\
\hline & & 0 & & & 0 & \\
\hline DW-Test & & 2.060172 & & & 2.284581 & \\
\hline Observations & & 120 & & & 120 & \\
\hline
\end{tabular}

***, ${ }^{* *}$ and ${ }^{*}$ indicated the significant level at the $0.01,0.05$ and 0.1 , respectively.

size of share companies (SIZE, sig.1\%) indicate a positive impact on share company financial performance of ROA. The board of directors meeting attendance rate (BDMAR) in person has a positive association with share company's financial performance of return on assets but not statistically significant. On the second model Table 6, presents the results of a FGLS regression with a robust standard error of corporate governance practices on Share Company's financial performance of ROE in Ethiopia. The result show that ROE has a significant positive association with board meeting frequency $(p<0.05)$; board of directors' gender diversity $(p<0.05)$ and size of share company $(p<0.01)$. Board of directors meeting attendance rate in person has a significant and negative relationship with $\mathrm{ROE}$ of $(p<0.01)$. However, not significant but negative association is found between ROE with board size and board of directors' leadership practice.

The results of the FGLS revealed that corporate governance practice 
variables in the first and second model are good fit with R-square value of 84 and $93 \%$. This implies that the corporate governance practice explanatory variables used in the study able to explain the explained variable financial performance (ROA) and (ROE) to the extent of 84 and $93 \%$ the remainder percentage is unexplained portion due to errors and other factors. The t-statistics of most of the explanatory variables are significant at 5\% significant level implies both models are good at most of explanatory variables in the study. In addition, the F-statistics for the first and second model is also statistically significant at zero $p$-values to five decimal palaces and having the statistical values of 16.73 and 42.38, respectively which confirms that the overall significance of the prediction power of the regression models of the study assuring the goodness of fit of the regression.

Discussion on the implication of results: The finding shows board size has negative association with financial performances of share companies ROA (at 5\% sig.) and ROE (not sig.). The first hypothesis is not accepted. The finding implies that the larger the board size the weaker the financial performance. The results of this study comply with similar empirical findings when there are many board members, it might be difficult to reach agreements, and therefore the board might be less efficient as board size increases $[19,47,56]$ and consistent with economics and social psychology theories about decision making which argued that a group's final decision is a compromise of varied opinions and Business Roundtable [10], support smaller boards often are more cohesive and work more effectively than larger boards. Therefore, this study identifies board size and composition is important determinants of board of directors' effectiveness. The size should be large enough to secure sufficient expertise on the board, but not so large that productive discussion is impossible and free-riding among directors is prevalent; a board of directors should have a mix of inside or executive and outside or independent board of directors with a variety of experience and core competence to make effective judgment on the management's performance objectively. Too big a board is likely to be less effective in substantive discussion of major issues and to suffer from free-rider problems among directors in their supervision of management.

Although, board size is an important attribute of board structure which is determined on the basis of how much it influences the communication and coordination and control management of a company [26] and one of the more contested areas in corporate governance concerns the role of boards of directors regarding strategy and innovation argued that the effectiveness of the size of the boards is contingent on business strategy and business environment [57-59]. It is contingent also on the characteristics of firms and government regulation pertaining to corporate governance [60]. Based on results there are companies with large board size but the board members have a limitation on skills and expertise on managing and designing strategies that could make their company profitable like diversification strategy, relates to a greater board size, to seize new market opportunities and utilize technological and financial capabilities more efficiently this is confirmed from interviewee.

The results indicated that board meeting frequency has statistically significant relationship, at $(p<0.05)$, with financial performance. The results revealed there is a negative association with return on assets and a positive association with return on equity. The hypothesis in model one is not accepted but empirically accepted in model two. This might be possible due to variation on the characteristics of board of directors meeting reaction (reactiveproactive) to the decision that they passed and its impact on performance and the other reason the existence of debts on the second model. Malik and Nehra [29] stated the more frequent the meetings, closer the supervision and control over managers, the more relevant would be the advisory role. All these will lead to a positive impact on the performance (proactive boards). On the other hand, frequent meetings (BMF) might also be a result of board's reaction to poor performance or reactive boards hence, this study empirically finds the boards frequency of meeting on return on assets point out the feature of a reactive board whereas on return on equity shows proactive boards characteristics indicating in consistencies of results. Further, this study complies with what Jensen [61,62] argues that boards of well-functioning firms should be relatively inactive and exhibit few conflicts. Frequently scheduled meetings generate costs including travel expenses, managerial time, administrative support and directors' meeting fees like refreshments. As a firm's performance declines, boards of directors are most likely to become more actively scrutinized by owners and are likely to meet more often to meet the declining value. The benefits to increased board of directors of the company's activity will include more time for boards of directors to discuss, set strategy and monitor management. Therefore, there could be a positive or negative relationship between board meeting frequency and financial performance measures what we call inconclusive result exists what actually matters are the context of the boards activity [63].

Studies empirically find a negative association between board meeting frequency and financial performance of a firm are [25,34,64]. According to Aguilera et al. [63] such inconsistencies in corporate governance research are common and can be explained by the fact that corporate governance-performance relationships seems to vary with respect to contexts. The decision is the impact of the board of directors meeting frequency on financial performance depends on the characteristics of performance the board meetings. If it is proactive for good performance where the benefits of the meeting out-weights the costs (managerial time, travel expenses, administrative support and directors' meeting fees) it has positive impact in model two (ROE). On the contrary, if it is reactive that is for poor performance where the cost of the meeting out-weights the benefits it results negative association in the first model (ROA). Board of directors' leadership practice has a negative association with financial performance at $1 \%$ sig level with return on assets but not significant with return on equity the results are as expected by the researcher and the hypothesis is accepted in both models. The negative association implies that if the CEO of the company has the role of chairperson in the board it has a negative impact on the financial performance. The result complies with agency theorists and empirical findings carried out. Agency theory argue that the same person should not hold the chief executive officer and chairman roles at the same time that will reduce the effectiveness of board monitoring roles [32].

Board of directors' gender diversity has a positive association with financial at significant level of $5 \%$. The results are as expected and the hypothesis is accepted in both models. The result contraindicated that the higher the proportion of female board of directors in the board room the better financial performance. That is female directors enhance boards of directors' effectiveness companies with higher proportion of women board of directors perform better than with lower proportion of women on their 
board room. Empirical confirmed that women board of directors are giving the benefits of improved financial performance, increased employee and customer satisfaction, improving investor confidence and greater market knowledge and reputation. Those analogous findings provide evidence on the positive and direct association between gender diversity in board room and corporate performance $[36,37,40,41,65]$. Since gender diversity helps to reduces corporate inefficiencies and enables companies to come closer to their optimal performance therefore, the Ethiopian companies should take the advantage of improving their company by involving more women in the governance structure.

Board of directors meeting attendance rate in person (BDMAR) shows insignificant positive association with return on assets but negative and significant association with return on equity at $1 \%$ significance level. The result implies that board of directors meeting attendance rate revealed not statistically significant relation or influence with return on assets as a proxy measure for financial performance of share companies. But the result showed BDMAR has a significant and negative effect on the performance of share companies' return on equity. The result entails that the higher the board of directors meeting attendance rate the lower the return on equity due to the poor performance of the meeting outcome that causes the cost of the meeting of the attendees out-weight the benefits of the meeting (return on equity). The newly issued corporate governance directive stated every director is expected to attend in person at least $75 \%$ of the board meetings within a year. This study not able to show adequate empirical support to this restriction regular board meeting attendance is important in improving the effectiveness of a governance system [43]. The control variable size of share companies (SIZE) has a positive and significant association with return on assets and return on equity at $1 \%$ significant level entails the larger the total assets of share companies the better the financial performance of the company that is consistent with earlier studies [66-73].

\section{CONCLUSIONS AND POLICY IMPLICATIONS}

The study result proved board of directors lack the required skill like diversification strategy relates to a greater board size, to seize new market opportunities and utilize technological and financial facilities more efficiently which was confirmed from interviewee too. Board of directors' frequency of meeting and board of directors meeting attendance rate in person depends on the attributes of performance of the board meetings performed. If it is proactive where the benefits of the meeting out-weights the costs it has positive impact on financial performance on the contrary, if it is reactive where the cost of the meeting out-weights the benefits its impact is negative on financial performance. Board room gender diversity has a positive and significant association with financial performance of share companies the result contraindicated that the higher the proportion of female board of directors in the board room of companies the better financial performance. The negative association between leadership practice and financial performance confirmed if the CEO of the company has the role of chairperson in the board it affects negatively the financial performance of the company and the involvement of female directors enhances boards of directors' effectiveness in companies where higher proportion of women board of directors performs better than those share companies with lower proportion of women on their board room. Duality has a negative impact which complies with agency theorists and empirical findings carried out on the subject and being owned by state means having a good governance practice which in turn shows better financial performance.

\section{LIMITATIONS OF THE STUDY AND DIREC- TION FOR FUTURE RESEARCH}

While corporate governance practices and its impact on corporate performance is all-round and widely applicable concept in different sectors this study is confined to financial sectors and representativeness of sampled share companiess in terms of much broader or wider Ethiopian companies' corporate governance environment can be extended by taking into account other corporate sectors. For the purpose of gauging the financial performance of share companies the market measures were not taken into consideration only the accounting measures of financial performance used because of the absence of organized stock market that limits to get the market data. The long term measures of performance were not considered. Therefore, this research work could be extended by taking into account other internal corporate governance practices which is not considered and external corporate governance practices not considered.

\section{RECOMMENDATIONS}

- Share companies' boards of directors should be suitably composed of non-executives and truly independent members professionally competent as well as able to provide a mixture of core competencies.

- Share companies should consider their board room gender diversity in the governance structure it has a positive impact and helps to reduces share companies' inefficiencies.

- The CEO of the share companies should not have the role of chairperson in the board leader ship practice since it affects negatively the financial performance of the company.

\section{ACKNOWLEDGEMENTS}

First of all, I am very grateful for Professor G.S. Batra, Head, School of Management Studies and dean Faculty of Business Studies Punjabi University, Patiala for his guidance and constructive comments on this paper work. Secondly, I would also like to express my indebtedness for Professor Bruce Hearn from Sussex University UK for his priceless critical evaluation, comments and suggestions in the $\mathrm{Ph}$. D workshop in corporate governance organized by Hanken Center for Corporate Governance, Helsinki Finland. Thirdly, I am also thankful to Hanken Center for Corporate Governance Helsinki Finland for its support in organizing Ph. D workshop in Corporate Governance for Ph. D students worldwide and assigning a discussant to evaluate the $\mathrm{Ph}$. D thesis chapters' work progress what is actually very imperative contribution for the growth of corporate governance scholars across the world. Lastly, I am thankful to Debremarkos University, Ethiopia for funding this research work.

\section{REFERENCES}

1. Hopt K. Comparative corporate governance: The state of the art and international regulation. American Journal of Comparative Law. 2011;59:1.

2. Brown DA. Public accounting at a crossroads. Remarks by the Chair of the Ontario Securities Commission to the Business Leaders 
Luncheon, sponsored by the Institute of Chartered Accountants of Ontario. 1999.

3. Levitt Jr A. The numbers game. The CPA Journal. 1998.

4. Al-Matari EMA. Corporate Governance and Performance of NonFinancial Public Listed Firms in Oman. 2014.

5. DeZoort FT, Salterio SE. The effects of corporate governance experience and financial-reporting and audit knowledge on audit committee members' judgments. Auditing: A Journal of Practice \& Theory. 2001;20:31-47.

6. Bonazzi L, Islam SM. Agency theory and corporate governance: A study of the effectiveness of board in their monitoring of the CEO. Journal of Modelling in Management. 2007;2:7-32.

7. Belverd EN, Marian P. Principles of Financial Accounting, (11thedn), South-Western Cengage Learning, United States of America. 2011.

8. Van Ness RK, Miesing P, Kang J. Understanding governance and corporate boards: Is theory a problem. European Journal of Management. 2009;7:186-199.

9. Fama EF, Jensen MC. Separation of ownership and control. The Journal of Law and Economics. 1983;26:301-325.

10. Business Roundtable. Principles of Corporate Governance. Washington, DC. 2012.

11. Eisenberg T, Sundgren S, Wells MT. Larger board size and decreasing firm value in small firms. Journal of Financial Economics. 1998;48:35-54.

12. Mak YT, Kusnadi Y. Size really matters: Further evidence on the negative relationship between board size and firm value. Pacific-Basin Finance Journal. 2005;13:301-318.

13. Hermalin BE, Weisbach MS. Boards of directors as an endogenously determined institution: A survey of the economic literature (No. w8161). National Bureau of Economic Research. 2001.

14. Yermack D. Higher market valuation of companies with a small board of directors. Journal of Financial Economics. 1996;40:185-211.

15. Loderer C, Peyer U. Board overlap, seat accumulation and share prices. European Financial Management. 2002;8:165-192.

16. Haniffa R, Hudaib M. Corporate governance structure and performance of Malaysian listed companies. Journal of Business Finance \& Accounting. 2006;33:1034-1062.

17. Hassan SU, Farouk MA. Board of Director's Characteristics and Performance of Listed Deposit Money Banks in Nigeria. Journal of Finance and Bank Management. 2014;2:89-105.

18. Nath SD, Islam S, Saha AK. Corporate Board Structure and Firm Performance: The Context of Pharmaceutical Industry in Bangladesh. International Journal of Economics and Finance. 2015;7:106-115.

19. Akpan EO, Amran NA. Board characteristics and company performance: Evidence from Nigeria. Journal of Finance and Accounting. 2014;2:81-89.

20. Othman R, Ponirin H, Ghani EK. The effect of board structure on shareholders' wealth in small listed companies in Malaysia. Management Science and Engineering. 2009;3:1-15.

21. Kathuria V, Dash S. Board size and corporate financial performance: an investigation. Vikalpa. 1999;24:11-17.

22. Chiang HT, Chia F. An empirical study of corporate governance and corporate performance. Journal of American Academy of Business. $2005 ; 6$.

23. Zakaria Z, Purhanudin N, Palanimally YR. Board governance and firm performance: A panel data analysis. Journal of Business Law and Ethics. 2014;2:1-12.

24. Ahmad A. How does corporate governance affect performance of banks in Palestine? Master of Business Administration. As part of the degree, School of Management. University of Bath. 2010.

25. Satirenjit KJ, Shireenjit K, Barry JC. Board Characteristics and Firm Performance: Evidence from Malaysian Public Listed Firms. Journal of Economics, Business and Management. 2014;3:239-243.

26. Saha AK, Akter S. Corporate governance and voluntary disclosure practices of financial and non-financial sector companies in Bangladesh. Journal of Applied Management Accounting Research. 2013;11:45-61.

27. Li Y. Governance, Regulation and Performance of Non-Listed Small Corporations in Australia: A Structural Equation Modeling Approach (Doctoral dissertation, Victoria University). 2014.

28. Adawi M, Rwegasira K. Corporate Governance and Firm Valuation in Emerging Markets: Evidence from UAE Listed Companies in the Middle East. Corporate Ownership \& Control. 2013;11:637-656.

29. Malik S, Nehra VS. Corporate Governance and Firms Performance: Review of research in the light of recent reforms in India. Pacific Business Review International. 2014;6:77-84.

30. Rahman HU, Ibrahim MY, Ahmad AC. Corporate Governance, Firm Financial Performance and Shareholders' Confidence: A Proposed Analysis of MCCG 2012. Global Business and Management Research. 2015;7:139-147.

31. Bliss MA. Does CEO duality constrain board independence? Some evidence from audit pricing. Accounting \& Finance. 2011;51:361. 380.

32. Finkelstein S, D'aveni RA. CEO duality as a double-edged sword: How boards of directors' balance entrenchment avoidance and unity of command. Academy of Management Journal. 1994;37:1079-1108.

33. Eulerich M, Velte P, Van Uum C. The impact of management board diversity on corporate performance an empirical analysis for the German two-tier system. Problems and Perspectives in Management. 2014;12:25-39.

34. Akpan EO. Corporate Board Meetings and Company Performance: Empirical Evidence from Nigerian Quoted Companies. Global Journal of Commerce \& Management Perspective. 2015;4:75-82.

35. Carter DA, Simkins BJ, Simpson WG. Corporate governance, board diversity, and firm value. Financial Review. 2003;38:33-53.

36. Farrell KA, Hersch PL. Additions to corporate boards: the effect of gender. Journal of Corporate finance. 2005;11:85-106.

37. McKinsey \& Company. Women matter 2010, women at the top of corporations: Making it happen. 2010.

38. Fondas N, Sassalos V. A Different Voice in the Boardroom: How the Presence of Women Directors Affects Board. Influence over Management. Global Focus. 2000;12.

39. Zelechowski DD, Bilimoria D. Characteristics of women and men corporate inside directors in the US Corporate governance: An International Review. 2004;12:337-342.

40. Terjesen S, Couto EB, Francisco PM. Does the presence of independent and female director's impact firm performance? A multi-country study of board diversity. Journal of Management \& Governance. 2016;20:447-483.

41. Catalyst. The bottom line: Connecting corporate performance and gender diversity. Catalyst. 2004.

42. Chou HI, Chung H, Yin X. Attendance of board meetings and company performance: Evidence from Taiwan. Journal of Banking \& Finance. 2013;37:4157-4171.

43. Min BS, Chizema A. Board Meeting Attendance by Outside Directors. Journal of Business Ethics. 2011;147:901-917. 
44. Manawaduge AS. Corporate governance practices and their impacts on corporate performance in an emerging market: The case of Sri Lanka. 2012.

45. Alalade YSA, Onadeko BB, Okezie OFC. Corporate Governance Practices and Firms' Financial Performance of Selected Manufacturing Companies in Lagos State, Nigeria. International Journal of Economics, Finance and Management Sciences. 2014;2:285-296.

46. Peters GT, Bagshaw KB. Corporate governance mechanisms and financial performance of listed firms in Nigeria: A content analysis. Global Journal of Contemporary Research in Accounting, Auditing and Business Ethics. 2014;1:103-128.

47. Ashenafi BF, Kelifa SK, Yodit KW. Corporate Governance and impact on Bank Performance. Journal of Finance and Accounting. 2013;1:19-26.

48. Asteriou D, Hall SG. Applied Econometrics: a modern approach, revised edition, Hampshire, Palgrave Macmillan. 2007.

49. Brook C. Introductory econometrics for finance. Cambridge University Press. 2014.

50. Agung IGN. Panel data analysis using EViews. John Wiley \& Sons. 2014.

51. Hsiao C. Analysis of panel data (No. 54). Cambridge Uuniversity Press. 2014.

52. Startz R. Eviews illustrated for version 7. Quantitative Micro Software. 2009.

53. Wooldridge JM. Introductory Econometrics: A Modern Approach. 2013.

54. Reed WR, Ye H. Which panel data estimator should I use? Applied Economics. 2011;43:985-1000

55. Lee CF, Lee JC, Lee AC. Statistics for Business and Financial Economics (3rded), Springer Science Business Media, New York. 2013.

56. Alabdullah TTY, Yahya S, Ramayah T. Corporate Governance Mechanisms and Jordanian Companies' Financial Performance. Asian Social Science. 2014;10:247.

57. Pearce JA, Zahra S. Board composition from a strategic contingency perspective. Journal of Management Studies. 1992;29:411-438.

58. Kiel GC, Nicholson GJ. Board composition and corporate performance: How the Australian experience informs contrasting theories of corporate governance. Corporate Governance: An International Review. 2003;11:189-205.
59. Ghofar A, Islam S. Corporate governance and contingency theory. Suiza, Springer International Publishing. 2015.

60. Guest PM. The impact of board size on firm performance: Evidence from the UK. The European Journal of Finance. 2009;15:385-404.

61. Jensen MC. The Modern Industrial Revolution, Exit, and the Failure of Internal Control Systems. Journal of Finance. 1993;48:831-880.

62. Jensen MC, Meckling WH. Theory of the Firm: Managerial Behavior, Agency Costs and Ownership Structure. Journal of Financial Economics. 1976;3:305-360.

63. Aguilera RV, Filatotchev I, Gospel H, Jackson G. An organizational approach to comparative corporate governance: Costs, contingencies, and complementarities. Organization Science. 2008;19:475-492.

64. Latif B, Sabir HM, Saleem S, Ali A. The Effects of Corporate Governance on Firm Financial Performance: A Study of Family and Non-Family Owned Firms in Pakistan. Research Journal of Finance and Accounting. 2014;5:75-89.

65. IFC (2012) Corporate Governance for Banks in Southeast Europe. World Bank Permissions Desk Office. Washington, DC.

66. Adams RB, Ferreira D. Women in the boardroom and their impact on governance and performance. Journal of Financial Economics. 2009;94:291-309.

67. Meyer JW. Reflections on institutional theories of organizations. The Sage handbook of organizational institutionalism. 2008.

68. Nordblom T. Corporate Governance in Banks Following the Financial Crisis: An institutional perspective on changes in the banking sector. Master's Thesis submitted for the Master of Science in Economics and Business Administration (Applied Economics and Finance) at Copenhagen Business School. 2013.

69. Powell WW. The International Encyclopedia of Organization Studies. Beverly Hills, CA: Sage Publishers. 2007.

70. Ross SA. The interrelations of finance and economics: Theoretical perspectives. American Economic Review. 1987;77:29-34.

71. Scott WR. Institutional theory: Contributing to a theoretical research program. Encyclopedia of Social Theory. 2004;1-47.

72. Licensing and Supervision of Insurance Business Corporate Governance Directives No. SIB/..../2015.

73. Licensing and Supervision of Banking Business Bank Corporate Governance Directives No. SBB/62/2015. 